\title{
HIGH-RESOLUTION MONITORING OF CURRENT RAPID TRANSFORMATIONS ON GLACIAL AND PERIGLACIAL ENVIRONMENTS
}

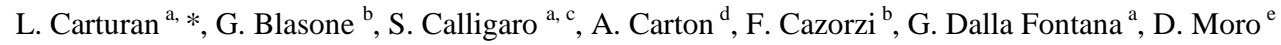 \\ ${ }^{a}$ Department of Land and Agroforest Environments, University of Padova, Legnaro (Padova), Italy - \\ luca.carturan@unipd.it \\ ${ }^{\mathrm{b}}$ Department of Agricultural and Environmental Sciences, University of Udine, Italy - (giacomo.blasone, \\ federico.cazorzi)@uniud.it \\ ${ }^{c}$ CIRGEO - Interdepartment Research Center of Geomatics, University of Padova, Legnaro (Padova), Italy - \\ smcll@libero.it \\ ${ }^{\mathrm{d}}$ Department of Geosciences, University of Padova, Italy - \\ alberto.carton@unipd.it \\ e Autonomous Region Friuli Venezia Giulia, Direzione centrale risorse rurali agroalimentari e forestali, Servizio del \\ corpo forestale regionale, Udine, Italy - daniele.moro@regione.fvg.it
}

KEY WORDS: climatic change, cryosphere degradation, terrestrial laser scanner, hydrogeological risk

\begin{abstract}
:
Glacial and periglacial environments are highly sensitive to climatic changes. Processes of cryosphere degradation may strongly impact human activities and infrastructures, and need to be monitored for improved understanding and for mitigation/adaptation. Studying glacial and periglacial environments using traditional techniques may be difficult or not feasible, but new remote sensing techniques like terrestrial and aerial laser scanner opened new possibilities for cryospheric studies. This work presents an application of the terrestrial laser scanner (TLS) for monitoring the current rapid changes occurring on the Montasio Occidentale glacier (Eastern Italian alps), which is representative of low-altitude, avalanche-fed and debris-cover glaciers. These glaciers are quite common in the Alps but their reaction to climate changes is still poorly known. The mass balance, surface velocity fields, debris cover dynamics and effects of meteorological extremes were investigated by repeat high-resolution TLS scanning from September 2010 to October 2012. The results were encouraging and shed light on the peculiar response of this glacier to climatic changes, on its current dynamics and on the feedback played by the debris cover, which is critical for its preservation. The rapid transformations in act, combined with the unstable ice mass, large amount of loose debris and channeled runoff during intense rainfalls, constitute a potential area for the formation of large debris flows, as shown by field evidences and documented by the recent literature.
\end{abstract}

\section{INTRODUCTION}

Glacial and periglacial environments are highly sensitive to climatic changes (Lemke et al., 2007). Their rapid evolution entails sudden changes of formerly glaciated terrain and of slopes which in the past were consolidated by permafrost (Haeberli \& Beniston, 1998; Chiarle et al., 2007; Gruber \& Haeberli, 2007; Sosio et al., 2008; Allen et al., 2009; Fischer, 2010; Huggel et al., 2010). These processes of cryosphere degradation may strongly impact human life, activities and infrastructures on alpine terrain, and need to be monitored for improved understanding and for the development of mitigation/adaptation strategies (Becker \& Bugmann 2001; Huggel et al., 2004; Kääb et al., 2005; Harris et al., 2009).

Studying glacial and periglacial environments using traditional techniques (e.g. total station surveys or direct mass balance measurements) may be difficult or not feasible, and assessing their current activity and dynamics may be problematic. New remote sensing techniques have led to a dramatic increase in terrain information (Tarolli et al., 2009) and opened new possibilities for cryospheric studies. Both the terrestrial and aerial laser scanner technologies provide cost effective, areawide observations with very high resolution. These methods have notable advantages over traditional survey techniques used on glacial and periglacial environments (e.g. Kodde et al. 2007; Knoll and Kerschner 2009; Abermann et al. 2010).

This work presents an application of the terrestrial laser scanner (TLS) for monitoring the current rapid changes occurring on glaciers and glacial forefields. The Montasio Occidentale glacier was selected as a first experimental site. This is the lowest Italian glacier and represents a type of glacier (lowaltitude, avalanche-fed and debris-covered) which is quite common in the European Alps, especially in the Dolomites. These glaciers show a peculiar behaviour compared to other alpine glaciers, and their reaction to climate changes is still poorly known. Repeat high-resolution TLS scanning were carried out from 2010 to 2012 on the Montasio Occidentale catchment to evaluate its mass balance, surface velocity fields, debris cover dynamics and effects of meteorological extremes (e.g. strong precipitation events, strong heat waves, heavy avalanche activity). The first results for the hydrological year 2010-'11 have been presented by Carturan et al., (2011, 2012 and 2013). In this paper we compare these results with new data collected in the year 2011-'12 (when meteorological conditions were rather different), which enabled the verification of some conclusions drawn by Carturan et al., (2013) concerning the response of this glacier to climatic changes.

\footnotetext{
* Corresponding author. This is useful to know for communication with the appropriate person in cases with more than one author.
} 


\section{STUDY AREA AND METHODS}

The Montasio Occidentale (World Glacier Inventory ID number: I4L0003005, WGMS, 1989) is a cone-shaped glacier, located at the base of the north walls of Mt. Jôf di Montasio (2754 m a.s.l., Figure 1), in the Italian Julian Alps (Eastern European Alps). The area-averaged mean elevation of the glacier is $1910 \mathrm{~m}$ a.s.1., ranging from 1860 to $2050 \mathrm{~m}$ a.s.1.. The glacier is currently composed of an upper, steep accumulation area and a lower, more gently sloping ablation area, that is covered by debris. The glacier's surface is $6.77 \mathrm{ha}$, and the major source of nourishment is avalanche snow from the above rock walls.

At the glacier's mean altitude the average annual air temperature, extrapolated from the weather station of Pontebba (561 $\mathrm{m}$ a.s.l. and $13 \mathrm{~km}$ north-west of the glacier) through the lapse rate calculated with the Mt. Lussari weather station (1760 $\mathrm{m}$ a.s.1., $\left.-6.1^{\circ} \mathrm{C} \mathrm{km}^{-1}\right)$, is $1.9^{\circ} \mathrm{C}$. The area is characterized by high precipitation amounts (Schwarb, 2000), reaching peak values above $3000 \mathrm{~mm} \mathrm{y}^{-1}$ in the Julian Prealps. The annual precipitation at the weather station of Pontebba during 19812010 averaged $1850 \mathrm{~mm}$.

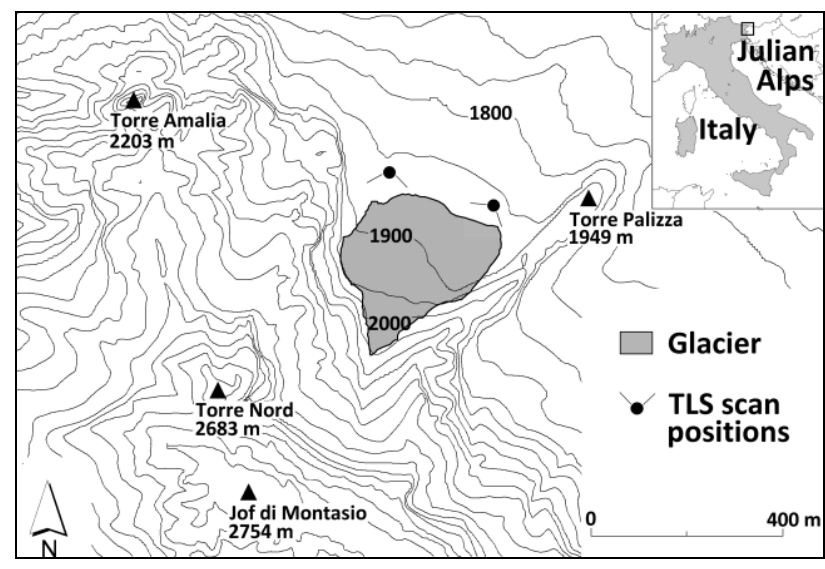

Figure 1. Geographic setting of Montasio Occidentale glacier.

Repeat high-resolution TLS scanning were carried out from 2010 to 2012 on the Montasio Occidentale catchment to evaluate the mass balance of the glacier, the surface velocity fields, the debris cover dynamics and the effects of meteorological extremes (e.g. strong precipitation events, strong heat waves, heavy avalanche activity). A combined approach was used combining TLS and differential GPS.

The Riegl LMS-Z620 TLS was used during the scanning sessions. This system, which operates in the near infrared wavelength region, provides a maximum measurement range of $2 \mathrm{~km}$, an accuracy of $10 \mathrm{~mm}$ at a distance of $100 \mathrm{~m}$ and an acquisition speed of up to 11000 point $\mathrm{s}^{-1}$. For every measured point, the scanner records the range, the horizontal and vertical alignment angles and the backscattered signal amplitude.

A differential GPS network was setup with dual-frequency GPS/GLONASS receivers (Topcon HiPer PRO) to georeference the TLS surveys in the global coordinate system UTM-WGS84 (Universal Transverse Mercator, zone 33, World Geodetic System 1984 datum).

Measurements were performed from two scan positions (Figure 1), located over the Little Ice Age terminal moraine, which provided good angles of incidence and good overall coverage of the catchment. The glacier was surveyed on five different dates:
23 September 2010, 31 May 2011, 29 September 2011, 17 May 2012 and 5 October 2012.

The raw topographic data (X, Y, Z measurements) acquired by the TLS were processed using the RiSCAN PRO (Riegl) and ArcGIS (ESRI) softwares to obtain a georeferenced mesh and to interpolate a Digital Terrain Model (DTM) with a cell size of 10 $\mathrm{x} 10 \mathrm{~cm}$. In addition, a higher resolution DTM (cell size of 5 x 5 $\mathrm{cm}$ ) was generated for the lower part of the glacier, which was closer to the TLS.

Elevation changes were calculated by differencing the DTMs acquired in the five different dates. The geodetic mass balance was then calculated converting the elevation changes into depths of water equivalent. The snow density, which was used for winter balance calculations, was measured on the glacier during the spring surveys and ranged from 550 to $590 \mathrm{~kg} \mathrm{~m}^{-3}$. For the net annual mass balance in 2011, we assumed an unchanged density structure of the glacier between September 2010 and September 2011, given the small change of the snowand firn-covered areas between the two dates (Sorge, 1935). Therefore, an ice density of $900 \mathrm{~kg} \mathrm{~m}^{-3}$ was used. In the following year a larger reduction of the firn area was observed and therefore the mean density was calculated by assuming a density of $650 \mathrm{~kg} \mathrm{~m}^{-3}$ for the old firn that was removed (Sapiano et al., 1998), obtaining a fractional area weighted mean of 825 $\mathrm{kg} \mathrm{m}^{-3}$. Snow free areas at the end of the two hydrological years in the lower part of the glacier, (where the $5 \times 5 \mathrm{~cm}$ DTM was available), were analyzed for evaluating the surface velocities by analyzing the displacement of debris on their surface. Training areas outside the glacier, over stable terrain, were used to assess the accuracy of individual measurements, which resulted $0.04 \mathrm{~m} \mathrm{y}^{-1}$ for the velocity and $0.12 \mathrm{~m}$ for the elevation differences at individual pixels.

\section{RESULTS AND DISCUSSION}

High seasonal and annual elevation changes occurred on the Montasio Occidentale glacier during the observation period (Figure 2). At the end of the two accumulation seasons large amounts of snow were detected, especially in the upper part of the glacier where frequent loose-snow avalanches accumulate. The thickness of the snowpack, assuming negligible elevation changes of the underlying glacier during the winter, ranged from 2 to $15 \mathrm{~m}$ in 2011 ( $7.5 \mathrm{~m}$ on average) and from 0.5 to 10 $\mathrm{m}$ in 2012 (4.1 $\mathrm{m}$ on average). The water equivalent (w.e.) of the accumulated snow was $4.2 \mathrm{~m}$ in 2011 and $2.4 \mathrm{~m}$ in 2012.

The spatial pattern of the annual elevation changes in the two years was similar in the lower part of the glacier, which is debris covered and which lowered by 0 to $1 \mathrm{~m}$. On the contrary, annual elevation changes were very different in the middle and upper parts of the glacier (Figure $2 b$ and d). In the first year lowering prevailed from 1900 to $1940 \mathrm{~m}$ a.s.1., while thickening occurred at higher altitudes. In the last year elevation losses of several meters ( $6 \mathrm{~m}$ on average) were observed in the entire upper part of the glacier, with a large gradient of elevation change around $1910 \mathrm{~m}$ a.s.1. The average elevation change was $-0.5 \mathrm{~m}$ in 2010-'11 and $-2.6 \mathrm{~m}$ in 2011-'12, which correspond to a net annual geodetic mass balance of -0.4 and $-2.1 \mathrm{~m}$ w.e. and to a summer balance of $-4.6 \mathrm{~m}$ and $-4.5 \mathrm{~m}$ w.e., respectively (Table $1)$. 


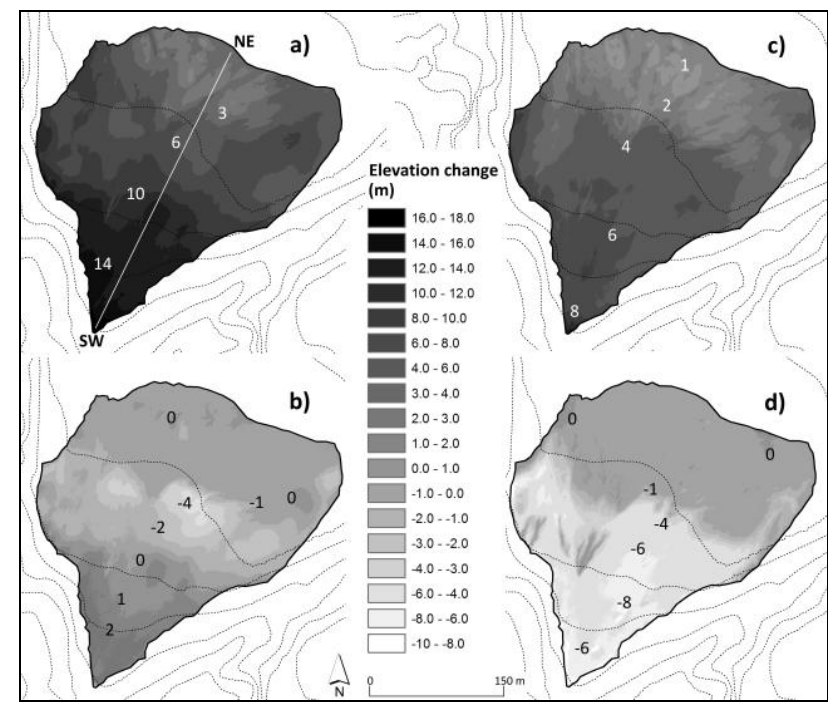

Figure 2. Elevation changes measured from a) September 2010 to May 2011, b) September 2010 to September 2011, c) September 2011 to May 2012 and d) September 2011 to October 2012. Digits represent elevation changes for each period.

The main differences between the two years, in terms of climatic conditions, concerned the precipitation during the accumulation season, while temperature differences during the ablation season were less relevant (Table 1).

The glacier response seems to be mainly driven by the precipitation anomalies, as suggested by Carturan et al., (2013) and by Serandrei Barbero et al. (1989). Interestingly, the summer balance was proportional to the air temperature anomaly in the ablation seasons, showing less ablation with warmer temperatures.

\begin{tabular}{|c|c|c|c|c|c|}
\hline Year & $\mathrm{P}_{\mathrm{an}}$ & $\mathrm{T}_{\mathrm{an}}$ & $\begin{array}{c}\mathrm{B}_{\mathrm{w}}(\mathrm{m} \\
\text { w.e. })\end{array}$ & $\begin{array}{c}\mathrm{B}_{\mathrm{s}}(\mathrm{m} \\
\text { w.e. })\end{array}$ & $\begin{array}{c}\mathrm{B}_{\mathrm{n}}(\mathrm{m} \\
\text { w.e. })\end{array}$ \\
\hline $\begin{array}{c}2010- \\
2011\end{array}$ & $+4 \%$ & $+0.7^{\circ} \mathrm{C}$ & 4.2 & -4.6 & -0.4 \\
\hline $\begin{array}{c}2011- \\
2012\end{array}$ & $-49 \%$ & $+1.0^{\circ} \mathrm{C}$ & 2.4 & -4.5 & -2.1 \\
\hline
\end{tabular}

Table 1. Climatic conditions at the weather station of Pontebba (561 m a.s.l., reference period 1981-2010) and mass balance observation on the Montasio Occidentale glacier. $\mathrm{P}_{\mathrm{an}}=$ precipitation anomaly in the accumulation season (November to April); $\mathrm{T}_{\mathrm{an}}=$ temperature anomaly in the ablation season (May to October); $\mathrm{B}_{\mathrm{w}}=$ winter balance, $\mathrm{B}_{\mathrm{s}}=$ summer balance; $\mathrm{B}_{\mathrm{n}}=$ annual net balance.

This paradox can be explained by the negative feedback exerted by the thick debris mantle which covers the glacier ice, thus reducing the ablation rates once snow and firn are depleted. As can be seen in Figure 3, the elevation changes were small below $1900 \mathrm{~m}$, during both years. This altitude separates the upper, mostly debris-free area from the lower, debris-covered area. In 2011 the higher elevation losses were detected in the elevation band from 1900 to $1930 \mathrm{~m}$, were the firn from previous years was exposed to summer ablation, while at higher altitudes the snow accumulated during winter persisted until the end of the ablation season, leading to net accumulation and thickening. In 2012 the snow accumulation did not counterbalance the high ablation caused by the warm summer temperatures, and the entire glacier experienced net ablation.

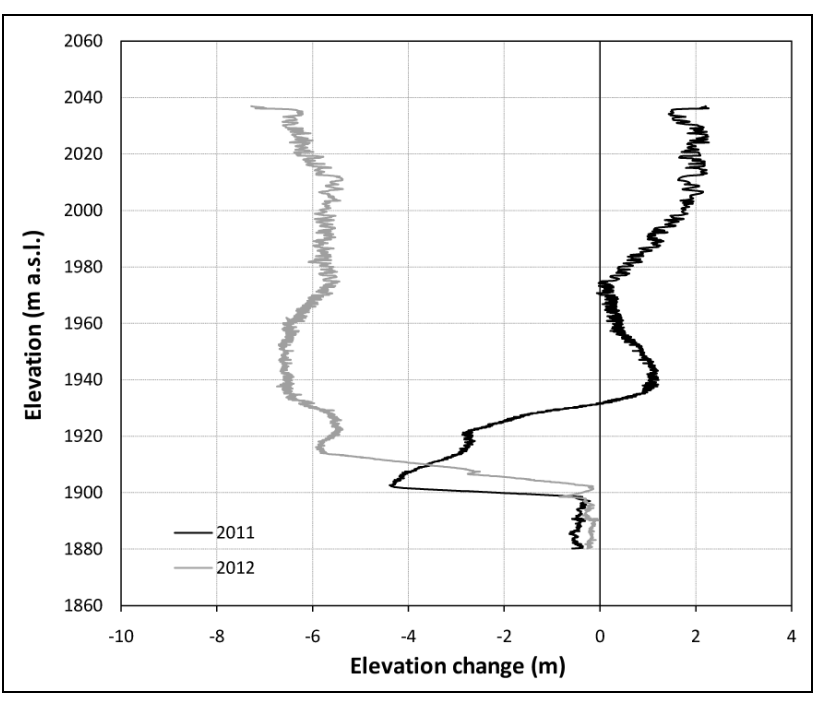

Figure 3. Elevation changes vs. elevation from September 2010 to September 2011 (black line) and from September 2011 to October 2012 (grey line) along the profile SW-NW in Figure $2 \mathrm{a}$.

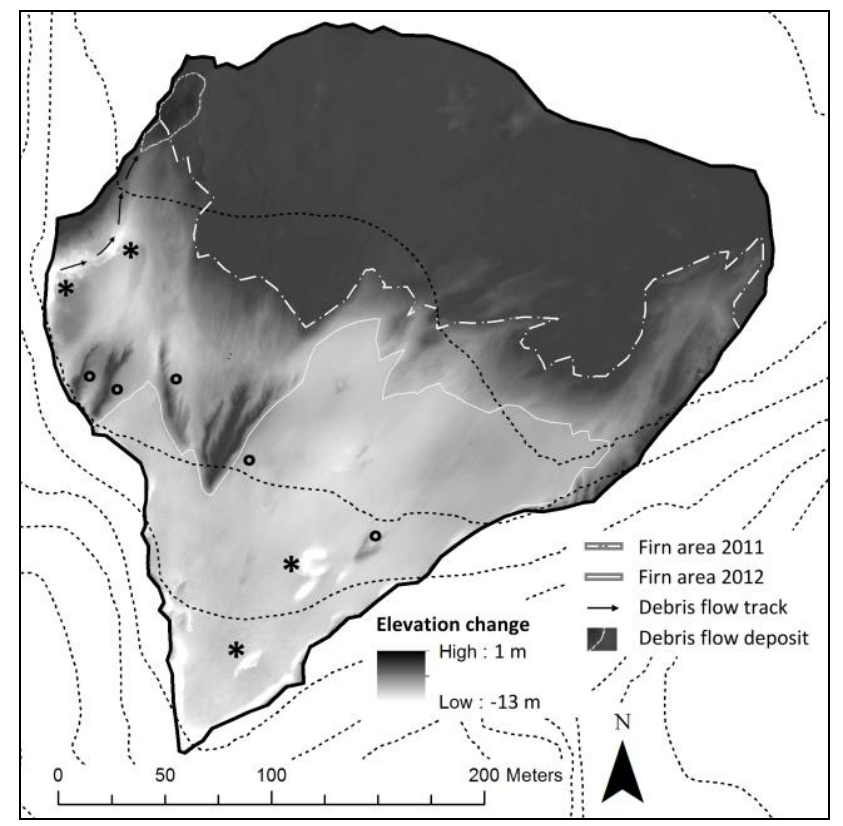

Figure 4. Spatial distribution of elevation changes and shrinking of the firn-covered area in the 2011-'12 hydrological year. Asterisks indicate collapse structures, circles indicate ridgeshaped features.

Figure 4 shows in higher detail the elevation changes from September 2011 to October 2012. As can be seen, the lowering of the glacier surface was closely related to the surface type which was exposed to ablation. Once the snow and firn have melted out in the lower half of the glacier, ablation rates sharply decreased due to the insulating effect of the debris layer on the buried ice. In the upper half of the glacier, were firn persisted throughout the summer, ablation rates remained high and led to a massive thinning of the ice body.

Overall, these evidences corroborates the findings of Carturan et al., (2013), which stressed a lower impact of air temperature and a higher importance of solid precipitation in controlling the 
mass balance of Montasio Occidentale glacier, and a complex response to climate changes, due to the feedback related to the thick debris cover.

Small areas collapsed in the upper portion of the glacier (Figure 4). The most likely cause of these collapses was the presence of sub-glacial cavities whose tops broke down once they reached a critical thickness, due to ablation. In the western part of the glacier a channeled runoff during intense rainfall may also have caused a collapse, or was dammed by a collapse possibly occurred during intense rainfall, leading to the formation of a small debris-flow (Figure 4 and 5). Due to the rapid melt of the firn, the ridge-shaped deposits which barely outcropped in the middle part of the glacier in 2011 were far larger and taller in 2012 (Figure 4).

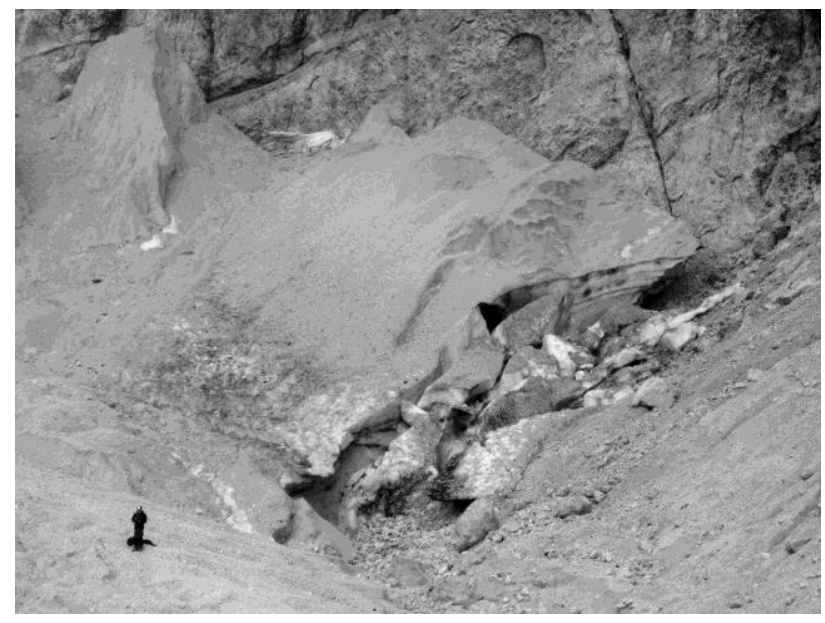

Figure 5. The collapsed area in the western portion of Montasio Occidentale glacier, at the starting zone of the small debris flow depicted in Figure 4 (photo S. Calligaro, 5 October 2012).

The presence of unstable ice areas along the glacier, the thick mantle of loose debris, and the occurrence of strong rainfalls which are channeled over (and inside) the glacier by the surrounding rock walls, represents a combination of factors which can lead to relevant hydrogeological risks, as reported by recent works which document the occurrence of debris flows in the glacier catchment during the 1990s and 2000s, as well as in other similar glaciers of the Alps (Del Longo et al. 2001; Moro et al. 2001; Chiarle et al. 2007). In particular, during retreat, glaciers leave large quantities of unconsolidated debris, unvegetated and often ice-cored. As described before, the Montasio Occidentale glacier is covered by a thick debris mantle in its lower half, mainly composed of loose sediments without vegetation cover. The shape of the glacier and of the overlying rock walls favor the concentration of surface runoff during intense precipitation, mainly towards the orographic left and right sides of the glacier where two notches interrupt the continuity of the LIA end moraine. Therefore, rapid saturation of the loose sediments in the lower part of the glacier can be triggered by the channeled runoff, facilitated by the underlying impermeable ice, eventually leading to debris flows across the above-mentioned notches. A further retreat of the glacier could have two opposite effects. On the one hand it would increase the availability of loose sediments, which currently makes part of the glacier. On the other hand, however, the progressive melt out of the ice core could favor the drainage throughout karst cavities likely existing at the bottom of the glacier.

The surface velocity in the lower part of the glacier was comparable in the two years, ranging from 0 to $35 \mathrm{~cm} \mathrm{y}^{-1}$ and averaging $20 \mathrm{~cm} \mathrm{y}^{-1}$ (Figure 6). Notably, the flow direction was more divergent in 2012 compared to 2011 , and this is quite surprising given the small time interval between the two observations. A possible explanation can be looked for in the very different thickness and spatial distribution of firn and snow in the accumulation area (Figure 4). In 2011 the upper and lateral (thick) avalanche deposits may have induced a slight deviation of the ice flow from the maximum slope direction, while in 2012 the displacement of the lower part of the glacier should have been dominated by the bedrock gradient, given the rapid shrinking and thinning of the accumulation area.

\section{CONCLUDING REMARKS}

The methods and instruments used for the two-year monitoring of the current rapid changes occurring on the Montasio Occidentale glacier provided good and interesting results. The entire glacier was effectively surveyed from two scanning positions using a terrestrial laser scanner (TLS), avoiding direct access to the glacier surface. TLS data enables the construction of very high resolution digital elevation models, which are highly important for analysis of the earth surface (Pirotti et al., 2013); in this case they were used for investigating the current dynamics of the glacier and the processes which regulate its response to climatic changes.

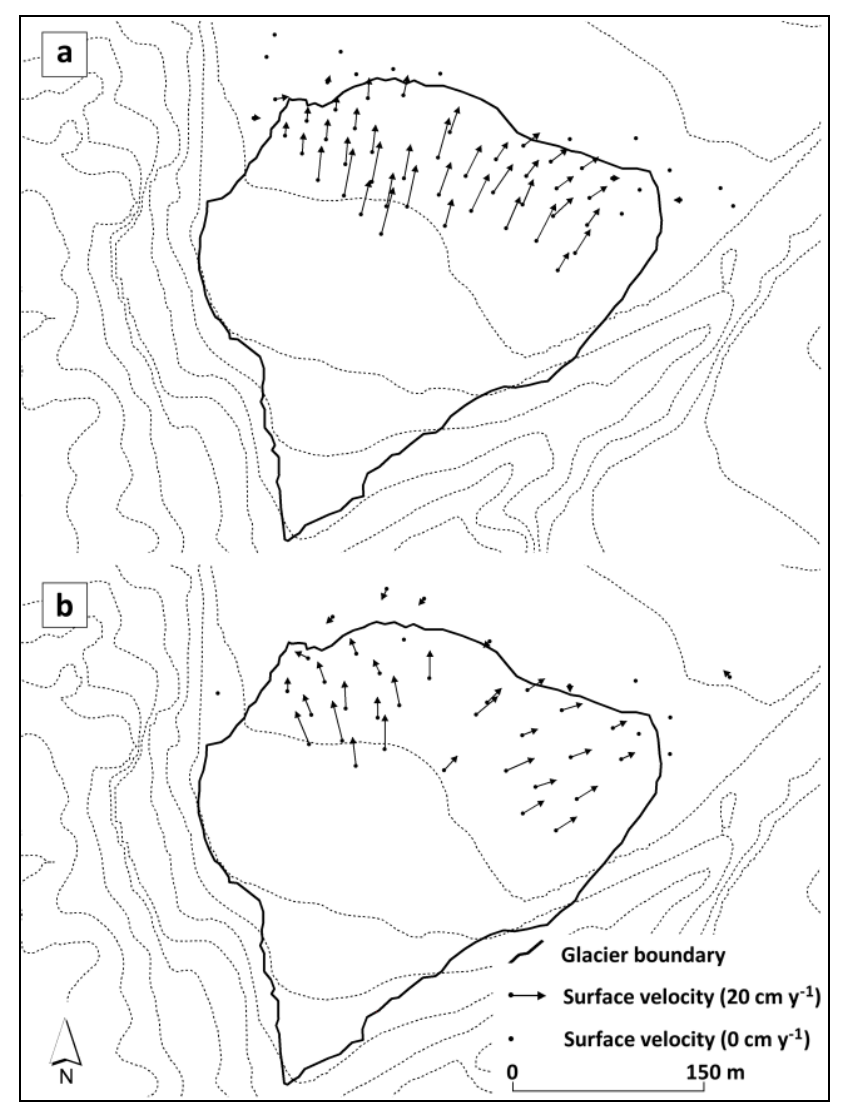

Figure 6. Annual surface velocities from September 2010 to September 2011 (a) and from September 2011 to October 2012 (b).

The very different climatic conditions in the two observed years, in particular for the winter snow accumulation, provided confirmations to the findings of Carturan et al., (2013), which inferred a high sensitivity of the glacier to the precipitation 
amounts in the winter season, and a rather low sensitivity to the summer temperatures. The thick debris cover strongly reduces the ablation rates, once the winter snow and the firn from previous years melt out. The surface displacement was similar in velocity but different in direction in the two years of observations.

These results are interesting and somewhat conflicting with field evidences from "normal" alpine glaciers (i.e. larger, debrisfree, at higher altitudes and with negligible avalanche accumulation), which in particular show a higher sensitivity to summer temperatures and prevailing positive feedbacks during deglaciation, e.g. lowering of the albedo, lowering of the surface, and increasing thermal emission from growing patches of ice-free terrain.

We note that, using traditional techniques such as direct mass balance measurements or total station surveys, it would not have been possible to collect the large amount of information gathered by TLS. Indeed, the traditional techniques would have provided much less information, despite requiring longer survey times and dangerous access to the glacier surface, which is steep, subject to avalanches and rock falls.

The investigated catchment shows potential hydrogeological risks, coming from the presence of a large amount of unconsolidated debris, an (impermeable) ice body which is partly buried by a thick debris mantle, a damming moraine ridge at the bottom of the glacier and steep rock walls which concentrate rainwater at the top of the glacier. As reported in the recent literature, debris flows originated in the past from this glacier and from other similar ice bodies in the Alps, which therefore need monitoring for risk prevention/mitigation, process understanding and modelling.

\section{REFERENCES}

Abermann, J., Fischer, A., Lambrecht, A. and Geist, T., 2010. On the potential of very high-resolution repeat DEMs in glacial and periglacial environments. The Cryosphere, 4, pp. 53-65.

Allen, K., Gruber, S. and Owens, I.F., 2009. Exploring steep bedrock permafrost and its relationship with recent slope failures in the Southern Alps of New Zealand. Permafrost and Periglacial Processes, 20, pp. 345-356.

Becker, A. and Bugmann, H., (eds.) 2001. Global Change and Mountain Regions. The Mountain Research Initiative. IGBP Report 49, Stockholm, 87 pp.

Carturan, L., Calligaro, S., Guarnieri, A., Milan, N., Tarolli, P., Moro, D., Baldassi, G.A., Cazorzi, F., Vettore, A. and Dalla Fontana, G., 2011. Terrestrial laser scanner survey of two small glacial formations in the Eastern Italian Alps. Geophysical Research Abstracts, 13, EGU2011-6204-1.

Carturan L., Calligaro, S., Cazorzi, F., Baldassi, G.A., Moro, D., Carton, A., Dalla Fontana, G., Guarnieri, A., Milan, N. and Tarolli. P., 2012. Mass balance and surface dynamics of Montasio Occidentale glacier (Eastern Italian Alps) investigated by Terrestrial Laser Scanner. Geophysical Research Abstracts, 14, EGU General Assembly 2012.

Carturan, L., Baldassi, G. A., Bondesan, A., Calligaro, S., Carton, A., Cazorzi, F., Dalla Fontana, G., Francese, R., Guarnieri, A., Milan, N., Moro, D., and Tarolli, P., 2013. Current behaviour and dynamics of the lowermost Italian glacier (Montasio Occidentale, Julian Alps), Geografiska Annaler: Series A, Physical Geography, 95, 79-96.
Chiarle, M., Iannotti, S., Mortara, G. and Deline, P., 2007. Recent debris flow occurrences associated with glaciers in the Alps. Global and Planetary Change, 56(1-2), pp. 123-136.

Del Longo, M., Finzi, E., Galgaro, A., Godio, A., Luchetta, A., Pellegrini, G.B. and Zambrano, R., 2001. Responses of the Val d'Arcia small dolomitic glacier (Mount Pelmo, Eastern Alps) to recent climatic changes. Geomorphological and geophysical study. Geografia Fisica e Dinamica Quaternaria, 24, pp. 4355.

Fischer, L., 2010. Slope instabilities on perennially frozen and glacierized rock walls: multi-scale observations, analysis and modelling. PhD thesis, University of Zürich, Zürich, Switzerland.

Gruber, S. and Haeberli, W., 2007. Permafrost in steep bedrock slopes and its temperature-related destabilization following climate change. Journal of Geophysical Research, 112, F02S18.

Haeberli, W. and Beniston, M., 1998. Climate change and its impact on glaciers and permafrost in the Alps. Ambio, 27, pp. 258-265.

Harris, C., Arenson, L.U., Christiansen, H.H., Etzelmüller, B., Frauenfelder, R., Gruber, S., Haeberli, W., Hauck, C., Hölzle, M. and Humlum, O., 2009. Permafrost and climate in Europe: Monitoring and modelling thermal, geomorphological and geotechnical responses. Earth-Science Reviews, 92(3-4), 117171.

Huggel, C., Haeberli, W., Kääb, A., Bieri, D. and Richardson, S., 2004. An Assessment Procedure for Glacial Hazards in the Swiss Alps. Canadian Geotechnical Journal, 41, pp. 10681083.

Huggel, C., Salzmann, N., Allen, S., Caplan-Auerbach, J., Fischer, L., Haeberli, W., Larsen, C., Schneider, D. and Wessels, R., 2010. Recent and future warm extreme events and high mountain slope failures. Philosophical Transactions of the Royal Society, 368, pp. 2435-2459.

Kääb, A., Reynolds, J.M. and Haeberli, W., 2005. Glacier and permafrost hazards in high mountains. In: Huber, U.M., Burgmann, H.K.H. and Reasoner, M.A. (eds): Global Change and Mountain Regions (A state of Knowledge overview). Springer, Dordrecht, pp. 225-234.

Knoll, C. and Kerschner, H., 2009. A glacier inventory for South Tyrol, Italy, based on airborne laser scanner data. Annals of Glaciology, 53, pp. 46-52.

Kodde, M.P., Pfeifer, N., Gorte, B.G.H., Geist, T. and Höfle, B., 2007. Automatic glacier surface analysis from airborne laser scanning. International Archives of Photogrammetry and Remote Sensing, 36, pp. 221-226.

Lemke, P., Ren, J., Alley, R.B., Allison, I., Carrasco, J., Flato, G., Fujii, Y., Kaser, G., Mote, P., Thomas, R.H. and Zhang, T. 2007. Observations: Changes in Snow, Ice and Frozen Ground. In: Climate Change 2007: The Physical Science Basis. Contribution of Working Group I to the Fourth Assessment Report of the Intergovernmental Panel on Climate Change, Cambridge University Press, pp. 337-383.

Moro, D., 2001. Il ghiacciaio che non c'era [The glacier that was not there]. Neve e Valanghe, 43, pp. 42-43.

Pirotti, F., Guarnieri, A., Vettore, A. 2013. State of the art of ground and aerial laser scanning technologies for high- 
resolution topography of the earth surface. European Journal of Remote Sensing, 46, pp. 66-78.

Sapiano, J.J., Harrison, W.D. and Echelmeyer, K.A., 1998. Elevation, Volume and Terminus Changes of Nine Glaciers in North America. Journal of Glaciology, 44(146), pp. 119-135.

Schwarb, M., 2000. The alpine precipitation climate. Evaluation of a high-resolution analysis scheme using comprehensive rain-gauge data. $\mathrm{PhD}$ diss., Swiss Federal Institute of Technology, Zürich, Switzerland.

Serandrei Barbero, R., Rabagliati, R. and Zecchetto, S., 1989. Analisi delle misure alle fronti dei ghiacciai delle Alpi Giulie e correlazioni con i dati climatici [Analysis of the length changes of Julian Alps glaciers and correlation with climatic data]. Geografia Fisica e Dinamica Quaternaria, 12, pp. 139-149.

Sorge, E., 1935. Glaziologische Untersuchungen in Eismitte [Glaciological Research at Eismitte]. In: Wissenschaftliche Ergebnisse der Deutschen Groenland Expedition Alfred Wegener 1929 und 1930-31, vol. 3, 270. F.A. Brokaus, Leipzig.

Sosio, R., Crosta, G.B. and Hungr, O., 2008. Complete dynamic modeling calibration for the Thurwieser rock avalanche (Italian Central Alps). Engineering Geology, 100, pp. 11-26.

Tarolli, P., Arrowsmith, J.R. and Vivoni, E.R., 2009. Understanding earth surface processes from remotely sensed digital terrain models. Geomorphology, 113, pp. 1-3.

\section{Acknowledgements}

This work was made feasible by the logistic support of the Autonomous Region Friuli Venezia Giulia (Direzione centrale risorse rurali agroalimentari e forestali, Servizio del corpo forestale regionale, and Protezione Civile). Investigations were founded by the P.R.I.N. 2010-2011 Project 'Dinamica dei sistemi morfoclimatici in risposta ai cambiamenti globali e rischi geomorfologici indotti' (Adm. C. Baroni). The data were processed by the Interdepartmental Research Center of Geomatics of the University of Padova (CIRGEO). 